\title{
Lipoprotein(a) in an adult sample from the Russian population: distribution and association with atherosclerotic cardiovascular diseases
}

\author{
Marat V. Ezhov'1, Svetlana A. Shalnova², Elena B. Yarovaya3, Vladimir A. Kutsenko3, \\ Svetlana E. Evstifeeva ${ }^{2}$, Victoria A. Metelskaya ${ }^{2}$, Oxana M. Drapkina² ${ }^{2}$ Sergey A. Boytsov ${ }^{1}$
}

${ }^{1}$ National Medical Research Center of Cardiology, Russia

${ }^{2}$ National Medical Research Center of Therapy and Preventive Medicine, Russia

${ }^{3}$ Lomonosov Moscow State University, Russia

Submitted: 11 October 2020

Accepted: 2 December 2020

Arch Med Sci

DOI: https://doi.org/10.5114/aoms/131089

Copyright $\odot 2021$ Termedia \& Banach

\section{Abstract}

Introduction: Lipoprotein(a) (Lp(a)) is recognized as an independent risk factor for atherosclerotic cardiovascular disease (ASCVD). The aim of this study was to estimate the distribution of Lp(a) levels in working age adults from the Russian population and to assess its association with ischemic heart disease (IHD), myocardial infarction (MI), stroke, diabetes mellitus (DM), and arterial hypertension (AH).

Material and methods: This substudy of the population-based study "Epidemiology of Cardiovascular Diseases and their Risk Factors in Some Regions of the Russian Federation" (ESSE-RF) included 8461 subjects aged 25-64 years (63.7\% women) without lipid-lowering drugs. Atherosclerotic cardiovascular disease was self-reported. Lp(a), apolipoproteins AI and B, and lipid and glucose levels in blood serum were determined.

Results: The prevalence of $L p(a) \geq 30 \mathrm{mg} / \mathrm{dl}$ was $20.5 \%$ and $23.0 \%$, and prevalence of $L p(a) \geq 50 \mathrm{mg} / \mathrm{dl}$ was $13.3 \%$ and $15.2 \%$, in men and women, respectively. An association of $\mathrm{Lp}(\mathrm{a})$ with IHD, MI, and AH, but not with stroke and DM, was shown. A cut-off level of $L p(a)$ of $9 \mathrm{mg} / \mathrm{dl}$ was determined, above which there was increased frequency of $\mathrm{MI}$ (by $59.2 \%, p=0.02$ ), IHD (by $33.4 \%, p<0.001$ ), and $\mathrm{AH}$ (by $11.6 \%, p<0.001$ ). In the multivariate analysis only the association of $\operatorname{Lp}(\mathrm{a})$ with IHD (1.19 (1.01-1.41), $p=0.038)$ and $\mathrm{MI}$ (1.57 (1.06-2.38), $p=0.028)$ remained significant.

Conclusions: Lipoprotein(a) level $\geq 30 \mathrm{mg} / \mathrm{dl}$ was detected in every fifth adult aged 25-64 years. Increased risk of MI and IHD starts at an Lp(a) serum level above $9 \mathrm{mg} / \mathrm{dl}$.

Key words: lipoprotein(a), distribution, ischemic heart disease, myocardial infarction.

\section{Introduction}

Lipoprotein(a) is recognized as an independent risk factor for atherosclerotic cardiovascular diseases (ASCVD) [1]. Large epidemiological and genetic studies have proven a causal link between $L p(a)$ and ischemic heart disease (IHD) [2, 3]. Lipoprotein(a) contains apolipoprotein(a) (apo(a)), which is attached to an apoB-100-containing low-density lipoprotein (LDL)-like particle and oxidized phospholipids [4]. Various studies have demonstrated the atherogenic, thrombogenic, and pro-inflamma-
Corresponding author: Marat V. Ezhov

National Medical Research Center of Cardiology

3rd Cherepkovskaya St 15a

121552, Moscow, Russia

E-mail: marat_ezhov@mail.ru 
tory properties of $\operatorname{Lp}(\mathrm{a})[5]$. There is wide variation in $\mathrm{Lp}(\mathrm{a})$ concentration in blood serum, from trace amounts $(<0.1 \mathrm{mg} / \mathrm{dl})$ to extremely high values (>300 $\mathrm{mg} / \mathrm{dl}$ ), while the target Lp(a) level is considered to be $50 \mathrm{mg} / \mathrm{dl}$ in Europe [6] and $30 \mathrm{mg} / \mathrm{dl}$ in the US and Canada [7, 8]. In addition, in a large Danish observational study involving 45,000 subjects, Lp(a) was shown to increase the risk of myocardial infarction (Ml) in men at values $\geq 10 \mathrm{mg} / \mathrm{dl}$ [9]. In the same population, the prevalence of hyperlipoproteinemia(a) (HLp(a)) ( $\mathrm{Lp}(\mathrm{a}) \geq 50 \mathrm{mg} / \mathrm{dl})$ was about $20 \%$ of adults, in both males and females [1]. In the Russian Federation, studies on the role of $L p(a)$ in atherosclerosis and its correction have been carried out for 30 years [10, 11], whereas information on the prevalence of $H L p(a)$ and the association of $\operatorname{Lp}(\mathrm{a})$ with the presence of IHD, MI, and stroke, at the population level is lacking. The "Epidemiology of Cardiovascular Risk Factors and Diseases in Regions of the Russian Federation" Study (ESSE-RF) is a large multicenter population-based study that includes assessment of risk factors and ASCVD prevalence in Russian adults [12]. The aim of this sub-study was to assess the distribution of Lp(a) levels in a sample of adults aged 25-64 years from the Russian population and evaluate the association of $L p(a)$ level with the presence of IHD, MI, stroke, diabetes mellitus (DM), and arterial hypertension (AH).

\section{Material and methods}

The design of the ESSE-RF study was reported earlier [12]. Briefly, the ESSE-RF is a multicenter population-based study in randomly selected district outpatient departments (Trial Registration Clinicaltrials.gov (NCT04306822)). The study included 12 regions from all 8 federal areas in Russia: the North Ossetia (Alania) Republic (North Caucasus), Volgograd (South), Vologda (NorthWest), Voronezh (Central), Ivanovo (Central), Kemerovo (West Siberia), Krasnoyarsk (East Siberia), Orenburg (Volga Region), Vladivostok (Far East), St. Petersburg (North West), Tomsk (West Siberia), and Tyumen (Ural) with a total of 24,000 participants. In this sub-study, information from Vologda, Ivanovo, Tyumen, Tomsk, the Primorsky regions, and North Ossetia was included. From the total cohort $3 \%$ of subjects received lipid-lowering treatment. Of 8461 subjects for whom all data were completed and who were not taking lipid-lowering drugs, 5389 (63.7\%) were women and 3072 (36.3\%) were men.

The study was approved by the independent ethics committees of: the National Medical Research Centre of Therapy and Preventive Medicine, Approval \# 07-03/12 dated 03.07.2012; the National Medical Research Centre of Cardiology, Approval \#180, 26.11.2012; the Federal Centre of Heart, Blood and Endocrinology named after V.A. Almazov, Approval \#193, 08.10.2012. All subjects gave signed informed consent. All subjects were surveyed using a standard questionnaire that included social and demographic characteristics, a history of diseases, and any therapy. The diagnosis of ASCVD was determined by self-reporting of the following: IHD, MI, stroke. Arterial hypertension and DM were registered in the case of elevated blood pressure and glucose level or appropriate treatment. Waist circumference, height, and weight measurements were taken in all subjects. Body mass index (BMI) was calculated by dividing weight by height squared $\left(\mathrm{kg} / \mathrm{m}^{2}\right)$.

Blood was drawn after overnight fasting; serum was obtained by low-speed centrifugation, aliquoted, frozen immediately and stored at $-80^{\circ} \mathrm{C}$. Analyses were performed at the central standardized laboratory using an Abbott Architect c8000 autoanalyser with Abbott Diagnostic kits (USA). Total cholesterol (TC), low-density lipoprotein cholesterol (LDL-C), high-density lipoprotein cholesterol (HDL-C) and triglycerides (TG) were measured by enzymatic methods; glucose level was determined by the hexokinase method, apolipoproteins (apo) Al and B concentration by immunoturbidimetric assay. For Lp(a) determination we used latex particle-enhanced turbidimetric immunoassay, which does not depend on the apo(a) isoform size. The LDL-C corrected for Lp(a)-cholesterol was calculated using the formula: LDL-Ccorr $(\mathrm{mmol} / \mathrm{l})=\mathrm{LDL}-\mathrm{C}(\mathrm{mmol} / \mathrm{l})-0.3 \times(\mathrm{Lp}(\mathrm{a})(\mathrm{mg} / \mathrm{dl}) /$ 38.7) [13].

The cut-off values for parameters of lipid profiles indicating hyperlipoproteinemia were determined as follows: total cholesterol $\geq 5.0 \mathrm{mmol} / \mathrm{l}$, $\mathrm{LDL}-\mathrm{C} \geq 3.0 \mathrm{mmol} / \mathrm{l}$; TG $\geq 1.7 \mathrm{mmol} / \mathrm{l}$; and $\mathrm{HDL}-\mathrm{C}$ $\leq 1.0 \mathrm{mmol} / \mathrm{l}$ and $\leq 1.2 \mathrm{mmol} / \mathrm{l}$, respectively, for men and women [6]. Prevalence of HLp(a) was described with two Lp(a) cut-off points: $30 \mathrm{mg} / \mathrm{dl}$ and $50 \mathrm{mg} / \mathrm{dl}$. Standardization and quality control of the analyses were carried out in accordance with the requirements of the federal system for external quality assessment of clinical laboratory studies (IACCO).

Statistical analysis was performed using SPSS 26 (IBM, Armonk, NY, USA) and R 3.5.1 (R Foundation for Statistical Computing, Vienna, Austria). Pearson's $\chi^{2}$ criterion was used to test the hypothesis of the normal distribution of variables. Continuous variables for which the hypothesis of normal distribution was not rejected are described by the mean and standard deviation; variables for which the hypothesis was rejected are described by the median and interquartile range $(25 \% ; 75 \%)$. Categorical variables are presented as a relative frequency and its $95 \%$ confidence interval $(\mathrm{Cl})$. For two independent 
Table I. Subjects' characteristics

\begin{tabular}{|c|c|c|c|c|}
\hline Variable & $\begin{array}{c}\text { Whole cohort } \\
\qquad N=8461\end{array}$ & $\begin{array}{c}\text { Men } \\
n=3072\end{array}$ & $\begin{array}{c}\text { Women } \\
n=5389\end{array}$ & $P$-value \\
\hline Age [years] & $48(36 ; 56)$ & $44(33 ; 54)$ & $49(39 ; 57)$ & $<0.001$ \\
\hline $\begin{array}{l}\mathrm{TC}[\mathrm{mmol} / \mathrm{l}] \\
{[\mathrm{mg} / \mathrm{dl}]}\end{array}$ & $\begin{array}{c}5.52 \pm 1.18 \\
212.53 \pm 45.29\end{array}$ & $\begin{array}{c}5.39 \pm 1.16 \\
207.53 \pm 44.80\end{array}$ & $\begin{array}{c}5.59 \pm 1.18 \\
215.38 \pm 45.33\end{array}$ & $<0.001$ \\
\hline $\begin{array}{l}\mathrm{HDL}-\mathrm{C}[\mathrm{mmol} / \mathrm{l}] \\
{[\mathrm{mg} / \mathrm{dl}]}\end{array}$ & $\begin{array}{c}1.41 \pm 0.33 \\
54.42 \pm 12.88\end{array}$ & $\begin{array}{c}1.28 \pm 0.3 \\
49.10 \pm 11.54\end{array}$ & $\begin{array}{c}1.49 \pm 0.33 \\
57.45 \pm 12.61\end{array}$ & $<0.001$ \\
\hline $\begin{array}{l}\text { LDL-C [mmol/l]; } \\
{[\mathrm{mg} / \mathrm{dl}]}\end{array}$ & $\begin{array}{c}3.5 \pm 1.04 \\
134.64 \pm 40.03\end{array}$ & $\begin{array}{c}3.46 \pm 1.02 \\
133.02 \pm 39.09\end{array}$ & $\begin{array}{c}3.52 \pm 1.05 \\
135.57 \pm 40.53\end{array}$ & 0.004 \\
\hline $\begin{array}{l}\text { LDL-C } C_{\text {corr }}[\mathrm{mmol} / \mathrm{l}] \\
{[\mathrm{mg} / \mathrm{dl}]}\end{array}$ & $\begin{array}{c}3.33 \pm 1.02 \\
128.09 \pm 39.36\end{array}$ & $\begin{array}{c}3.30 \pm 1.01 ; \\
126.93 \pm 38.88\end{array}$ & $\begin{array}{c}3.34 \pm 1.03 \\
128.75 \pm 39.62\end{array}$ & 0.039 \\
\hline $\begin{array}{l}\text { TG }[\mathrm{mmol} / \mathrm{l}] \\
{[\mathrm{mg} / \mathrm{dl}]}\end{array}$ & $\begin{array}{c}1.18(0.84 ; 1.72) ; \\
104.43(74.34 ; 152.22)\end{array}$ & $\begin{array}{c}1.24(0.87 ; 1.9) ; \\
109.74(77.00 ; 163.72)\end{array}$ & $\begin{array}{c}1.14(0.82 ; 1.66) ; \\
100.89(72.57 ; 146.91)\end{array}$ & $<0.001$ \\
\hline ApoAl [g/l] & $1.60 \pm 0.42$ & $1.54 \pm 0.44$ & $1.64 \pm 0.39$ & $<0.001$ \\
\hline ApoB [g/l] & $0.90 \pm 0.25$ & $0.89 \pm 0.24$ & $0.91 \pm 0.25$ & 0.004 \\
\hline $\operatorname{Lp}(\mathrm{a})[\mathrm{mg} / \mathrm{dl}]$ & $10.9(4.7 ; 26.1)$ & $9.7(4.2 ; 22.52)$ & $11.5(5 ; 27.2)$ & $<0.001$ \\
\hline BMI $\left[\mathrm{kg} / \mathrm{m}^{2}\right]$ & $28.09 \pm 5.81$ & $27.58 \pm 4.75$ & $28.38 \pm 6.31$ & $<0.001$ \\
\hline Waist [cm] & $87.64 \pm 14.63$ & $92.34 \pm 13.11$ & $84.96 \pm 14.78$ & $<0.001$ \\
\hline Glucose $[\mathrm{mmol} / \mathrm{l}]$ & $5.08(4.67 ; 5.53)$ & $5.21(4.8 ; 5.67)$ & $5.01(4.59 ; 5.45)$ & $<0.001$ \\
\hline IHD, $n(\%)$ & $677(8.0)$ & $202(6.6)$ & $475(8.8)$ & $<0.001$ \\
\hline MI, $n(\%)$ & $111(1.3)$ & $73(2.4)$ & $38(0.7)$ & $<0.001$ \\
\hline Stroke, $n(\%)$ & $146(1.7)$ & $64(2.1)$ & $82(1.5)$ & 0.067 \\
\hline $\mathrm{DM}, n(\%)$ & $349(4.1)$ & $106(3.5)$ & $243(4.5)$ & 0.02 \\
\hline $\mathrm{AH}, n(\%)$ & $4132(48.8)$ & 1485 (48.3) & 2647 (49.1) & 0.50 \\
\hline
\end{tabular}

$A H$ - arterial hypertension, ApoAl - apolipoprotein Al, ApoB - apolipoprotein B, BMI - body mass index, DM - diabetes mellitus, HDL-C high-density lipoprotein cholesterol, IHD - ischemic heart disease, LDL-C - low-density lipoprotein cholesterol, LDL-Ccorr - corrected for lipoprotein(a) cholesterol, Lp(a) - lipoprotein(a), MI - myocardial infarction, TC - total cholesterol, TG - triglycerides.

groups, the hypothesis on the mean was tested using the unpaired Student's t-test for unequal variances. The Mann-Whitney $U$ test was used to compare the homogeneity of distribution in two groups. Contingency tables $(2 \times 2)$ were analyzed using Fisher's two-sided exact test.

Univariate and multivariate logistic regression models were used to assess the relationships between $\operatorname{Lp}(\mathrm{a})$ and diseases. Continuous variables in a series of regression models were transformed into binary variables, where the value "0" corresponded to a level less than the threshold value (for HDL-C level less than the threshold value), and the value " 1 " was assigned otherwise. A hypothesis on the significance of the area under the curve in the ROC analysis was tested using a bootstrap from the pROC R library [14]. The threshold value for $L p(a)$ was obtained for diseases with a significant association with $\operatorname{Lp}(a)$. The $\operatorname{Lp}(a)$ threshold values with a maximal sum of sensitivity and specificity for each disease were determined using ROC analysis. The mean of these values was considered as the cutoff point of $L p(a)$ for uni- variate and multivariate regression analyses for all diseases. In multivariate regression models, the diseases were the dependent variables. Variables such as age, sex, LDL-Ccorr, HDL-C, TG, waist circumference, and glucose were used as covariates. A $p$-value less than $0.05(p<0.05)$ was considered to be statistically significant.

\section{Results}

Baseline characteristics are presented in Table I. The median $L p(a)$ level was higher in women. Mean $L p(a)$ levels and frequencies of elevated $L p(a)$ ( $\geq 30 \mathrm{mg} / \mathrm{dl}, n=1871$ and $\geq 50 \mathrm{mg} / \mathrm{dl}, n=1228$ ) for both sexes in the different age groups are presented in Table II. Lipoprotein(a) levels were higher in women than in men in the 45-54-year and $55-64$-year age groups ( $p<0.0011$ for both).

The prevalence of $\operatorname{Lp}(a) \geq 30 \mathrm{mg} / \mathrm{dl}$ was $20.5 \%$ and $23 \%$, and the prevalence of $L p(a) \geq 50 \mathrm{mg} / \mathrm{dl}$ was $13.2 \%$ and $15.2 \%$, in men and women, respectively. Regardless of sex, the prevalence of $L p(a)$ $\geq 30 \mathrm{mg} / \mathrm{dl}$ was $22.1 \%$ and prevalence of $\operatorname{Lp}(\mathrm{a})$ $\geq 50 \mathrm{mg} / \mathrm{dl}$ was $14.5 \%$. Hyperlipoproteinemia(a) 
Marat V. Ezhov, Svetlana A. Shalnova, Elena B. Yarovaya, Vladimir A. Kutsenko, Svetlana E. Evstifeeva, Victoria A. Metelskaya, Oxana M. Drapkina, Sergey A. Boytsov

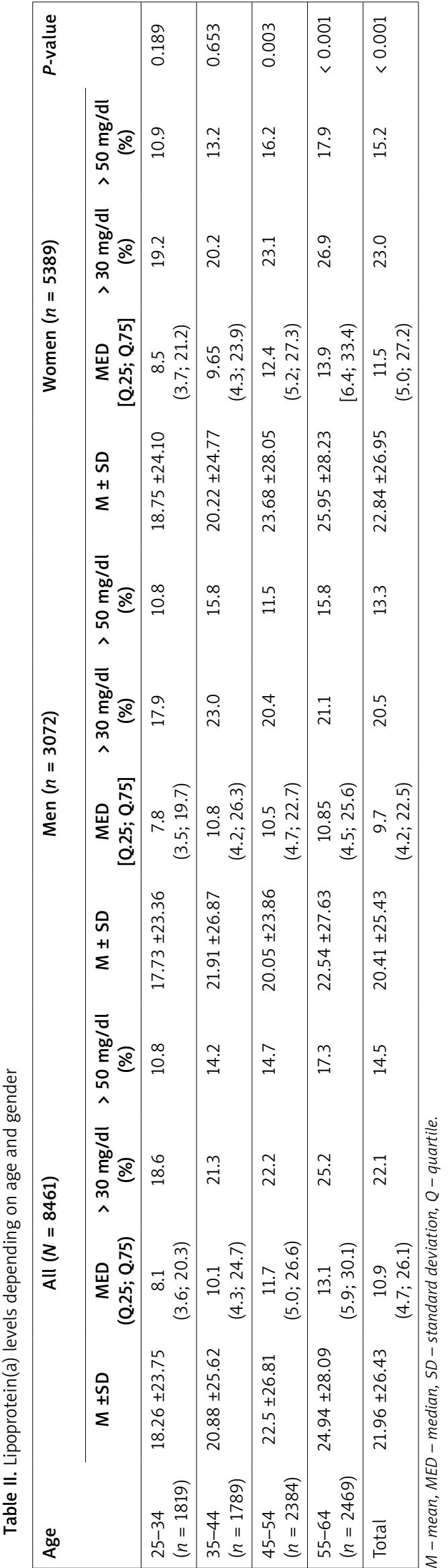

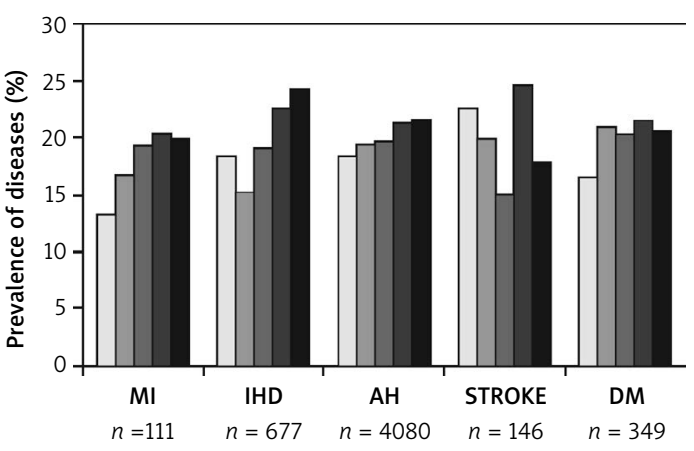

$\square \mathrm{Q} 1<4 \square 4 \leq \mathrm{Q} 2<8 \square 8 \leq \mathrm{Q} 3<15 \square 15 \leq \mathrm{Q} 4<35$

$5 \geq$ Q5

Figure 1. Disease distributions according to lipoprotein(a) quintiles

$A H$ - arterial hypertension, DM - diabetes mellitus, IHD - ischemic heart disease, $\mathrm{MI}$ - myocardial infarction.

frequency increased with age in women. The remarkable differences between the mean and median levels of $L p(a)$ were due to its abnormal distribution.

Atherosclerotic cardiovascular disease, $\mathrm{AH}$, and DM distribution according to $L p(a)$ quintiles is shown in Figure 1. A positive association between $\mathrm{Lp}(\mathrm{a})$ and $\mathrm{MI}$, IHD, and AH was found. The frequencies of $\mathrm{MI}, \mathrm{IHD}$, and $\mathrm{AH}$ were $13.3 \%, 18.3 \%$, and $18.4 \%$, respectively, in the first quintile, versus $19.9 \%, 24.2 \%$, and $21.5 \%$, respectively, in the fifth quintile ( $p<0.001$ for all three diseases). No association of $L p(a)$ with stroke or DM was found.

ROC analysis confirmed significant associations of $\operatorname{Lp}(\mathrm{a})$ with $\mathrm{MI}$ (AUC $=0.55,95 \% \mathrm{Cl}$ : 0.50-0.60, $p=0.036)$, IHD (AUC $=0.54,95 \% \mathrm{Cl}: 0.52-0.57$, $p<0.001)$, and $\mathrm{AH}(\mathrm{AUC}=0.53,95 \% \mathrm{Cl}: 0.52-$ $0.55, p<0.001$ ), but not with stroke (AUC $=0.50$, $p=0.851$ ) or DM (AUC $=0.52, p=0.221$ ). Cut-off values for $L p(a)$ with maximal sum of sensitivity and specificity were 5.65, 9.45, and $11.15 \mathrm{mg} /$ dl for MI, IHD, and $\mathrm{AH}$, respectively. The average of these obtained values was $8.75 \mathrm{mg} / \mathrm{dl}$, so for further analysis we used a cut-off level of $9 \mathrm{mg} / \mathrm{dl}$. A univariate binary logistic model demonstrated that $L p(a) \geq 9 \mathrm{mg} / \mathrm{dl}$ was associated with MI, IHD, and $\mathrm{AH}$ (Fig. 2). Univariate and multivariate models of associations of $\mathrm{Lp}(\mathrm{a})$ and other risk factors with $\mathrm{MI}, \mathrm{IHD}, \mathrm{AH}$, stroke, and DM are presented in Table III.

In the univariate model, all the risk factors listed in the methods were significantly associated with IHD and $\mathrm{AH}$, excepting sex for $\mathrm{AH}$. Age, sex, waist circumference and HDL-C level were significantly associated with $\mathrm{MI}$ and stroke. Age, lipid profile, and waist circumference but not sex and $\operatorname{Lp}(\mathrm{a})$ were significantly associated with DM. In the multivariate analysis, most associations weakened or disappeared; however, the association of $L p(a)$ with IHD (1.19 (1.01-1.41), $p=0.038)$ and MI (1.57 (1.06-2.38), 
Lipoprotein(a) in an adult sample from the Russian population: distribution and association with atherosclerotic cardiovascular diseases

Table III. Univariate and multivariate logistic regression for $L p(a)$, risk factors and diseases $(N=8461)$

\begin{tabular}{|c|c|c|c|c|}
\hline \multirow[t]{2}{*}{ Disease/Risk factor group* (with threshold value) } & \multicolumn{2}{|c|}{ Univariate model } & \multicolumn{2}{|c|}{ Multivariate model } \\
\hline & OR $(95 \% \mathrm{Cl})$ & $P$-value & OR $(95 \% \mathrm{Cl})$ & $P$-value \\
\hline \multicolumn{5}{|l|}{ IHD } \\
\hline Age $>45$ years & $11.57(8.70-15.80)$ & $<0.001$ & $9.29(6.88-12.80)$ & $<0.001$ \\
\hline Sex, male & $0.73(0.61-0.86)$ & $<0.001$ & $1.01(0.84-1.21)$ & 0.949 \\
\hline $\mathrm{LDL}-\mathrm{C}_{\text {corr }}>3 \mathrm{mmol} / \mathrm{l}$ & $1.70(1.43-2.03)$ & $<0.001$ & $1.02(0.85-1.23)$ & 0.845 \\
\hline $\mathrm{HDL}-\mathrm{C}<1 \mathrm{mmol} / \mathrm{l}$ for males, $1.2 \mathrm{mmol} / \mathrm{l}$ for females & $1.47(1.21-1.77)$ & $<0.001$ & $1.24(1.01-1.52)$ & 0.040 \\
\hline $\mathrm{TG} \geq 1.7 \mathrm{mmol} / \mathrm{l}$ & $1.90(1.61-2.23)$ & $<0.001$ & $1.21(1.01-1.45)$ & 0.038 \\
\hline Waist $\geq 102$ for males, $\geq 88$ for females & $2.79(2.38-3.27)$ & $<0.001$ & $1.69(1.42-2.01)$ & $<0.001$ \\
\hline Glucose $\geq 5.6 \mathrm{mmol} / \mathrm{l}$ & $1.91(1.62-2.26)$ & $<0.001$ & $1.18(0.99-1.42)$ & 0.068 \\
\hline $\mathrm{Lp}(\mathrm{a}) \geq 9 \mathrm{mg} / \mathrm{dl}$ & $1.37(1.16-1.61)$ & $<0.001$ & $1.19(1.01-1.41)$ & 0.038 \\
\hline \multicolumn{5}{|l|}{ MI } \\
\hline Age $>45$ years & $41.43(13.00-251.00)$ & $<0.001$ & $44.53(14.00-271.00)$ & $<0.001$ \\
\hline Sex, male & $3.43(2.33-5.13)$ & $<0.001$ & $4.79(3.17-7.32)$ & $<0.001$ \\
\hline $\mathrm{LDL}-\mathrm{C}_{\text {corr }}>3 \mathrm{mmol} / \mathrm{l}$ & $1.17(0.80-1.74)$ & 0.433 & $0.70(0.47-1.06)$ & 0.085 \\
\hline $\mathrm{HDL}-\mathrm{C}<1 \mathrm{mmol} / \mathrm{l}$ for males, $<1.2 \mathrm{mmol} / \mathrm{l}$ for females & $1.26(0.78-1.97)$ & 0.320 & $1.09(0.65-1.76)$ & 0.721 \\
\hline $\mathrm{TG} \geq 1.7 \mathrm{mmol} / \mathrm{l}$ & $1.96(1.33-2.87)$ & 0.001 & $1.28(0.84-1.93)$ & 0.245 \\
\hline Waist $\geq 102$ for males, $\geq 88$ for females & $1.86(1.27-2.70)$ & 0.001 & $1.53(1.01-2.32)$ & 0.042 \\
\hline Glucose $\geq 5.6 \mathrm{mmol} / \mathrm{l}$ & $2.64(1.80-3.85)$ & $<0.001$ & $1.41(0.94-2.11)$ & 0.090 \\
\hline $\operatorname{Lp}(\mathrm{a}) \geq 9 \mathrm{mg} / \mathrm{dl}$ & $1.60(1.08-2.41)$ & 0.020 & $1.57(1.06-2.38)$ & 0.028 \\
\hline \multicolumn{5}{|l|}{ Stroke } \\
\hline Age $>45$ years & $6.65(4.02-12.00)$ & $<0.001$ & $6.44(3.82-11.70)$ & $<0.001$ \\
\hline Sex, male & $1.38(0.99-1.91)$ & 0.057 & $1.91(1.34-2.70)$ & $<0.001$ \\
\hline $\mathrm{LDL}-\mathrm{C}_{\text {corr }}>3 \mathrm{mmol} / \mathrm{l}$ & $1.23(0.88-1.74)$ & 0.240 & $0.84(0.59-1.20)$ & 0.328 \\
\hline $\mathrm{HDL}-\mathrm{C}<1 \mathrm{mmol} / \mathrm{l}$ for males, $<1.2 \mathrm{mmol} / \mathrm{l}$ for females & $1.78(1.21-2.55)$ & 0.002 & $1.52(1.01-2.23)$ & 0.038 \\
\hline $\mathrm{TG} \geq 1.7 \mathrm{mmol} / \mathrm{l}$ & $1.74(1.24-2.43)$ & 0.001 & $1.11(0.77-1.60)$ & 0.580 \\
\hline Waist $\geq 102$ for males, $\geq 88$ for females & $2.46(1.77-3.43)$ & $<0.001$ & $1.84(1.28-2.66)$ & 0.001 \\
\hline Glucose $\geq 5.6 \mathrm{mmol} / \mathrm{l}$ & $1.69(1.18-2.38)$ & 0.003 & $1.00(0.68-1.43)$ & 0.979 \\
\hline $\mathrm{Lp}(\mathrm{a}) \geq 9 \mathrm{mg} / \mathrm{dl}$ & $0.94(0.68-1.30)$ & 0.700 & $0.86(0.62-1.20)$ & 0.382 \\
\hline \multicolumn{5}{|l|}{ DM } \\
\hline Age $>45$ years & $7.30(5.19-10.61)$ & $<0.001$ & $5.28(3.70-7.78)$ & $<0.001$ \\
\hline Sex, male & $0.76(0.60-0.95)$ & 0.019 & $1.12(0.87-1.44)$ & 0.363 \\
\hline $\mathrm{LDL}_{-} \mathrm{C}_{\text {corr }}>3 \mathrm{mmol} / \mathrm{l}$ & $1.23(0.99-1.55)$ & 0.067 & $0.70(0.55-0.89)$ & 0.004 \\
\hline $\mathrm{HDL}-\mathrm{C}<1 \mathrm{mmol} / \mathrm{l}$ for males, $<1.2 \mathrm{mmol} / /$ for females & $2.49(1.97-3.13)$ & $<0.001$ & $1.59(1.24-2.04)$ & $<0.001$ \\
\hline $\mathrm{TG} \geq 1.7 \mathrm{mmol} / \mathrm{l}$ & $3.77(3.04-4.69)$ & $<0.001$ & $2.33(1.84-2.95)$ & $<0.001$ \\
\hline Waist $\geq 102$ for males, $\geq 88$ for females & $4.98(3.95-6.33)$ & $<0.001$ & $2.92(2.27-3.78)$ & $<0.001$ \\
\hline Glucose $\geq 5.6 \mathrm{mmol} / \mathrm{l}$ & $16.99(13.00-22.50)$ & $<0.001$ & Not included & - \\
\hline $\operatorname{Lp}(\mathrm{a}) \geq 9 \mathrm{mg} / \mathrm{dl}$ & $1.14(0.92-1.42)$ & 0.24 & $1.04(0.83-1.31)$ & 0.716 \\
\hline
\end{tabular}


Marat V. Ezhov, Svetlana A. Shalnova, Elena B. Yarovaya, Vladimir A. Kutsenko, Svetlana E. Evstifeeva, Victoria A. Metelskaya, Oxana M. Drapkina, Sergey A. Boytsov

Table III. Cont.

\begin{tabular}{|c|c|c|c|c|}
\hline \multirow[t]{2}{*}{ Disease/Risk factor group* (with threshold value) } & \multicolumn{2}{|c|}{ Univariate model } & \multicolumn{2}{|c|}{ Multivariate model } \\
\hline & OR $(95 \% \mathrm{Cl})$ & $P$-value & OR $(95 \% \mathrm{Cl})$ & $P$-value \\
\hline \multicolumn{5}{|l|}{$\mathrm{AH}$} \\
\hline Age $>45$ years & $6.00(5.45-6.61)$ & $<0.001$ & $4.53(4.08-5.03)$ & $<0.001$ \\
\hline Sex, male & $0.97(0.89-1.06)$ & 0.491 & $1.30(1.17-1.45)$ & $<0.001$ \\
\hline $\mathrm{LDL}-\mathrm{C}_{\text {corr }}>3 \mathrm{mmol} / \mathrm{l}$ & $2.09(1.91-2.28)$ & $<0.001$ & $1.17(1.05-1.30)$ & 0.004 \\
\hline $\mathrm{HDL}-\mathrm{C}<1 \mathrm{mmol} / \mathrm{l}$ for males, $<1.2 \mathrm{mmol} / \mathrm{l}$ for females & $1.30(1.16-1.46)$ & $<0.001$ & $0.97(0.85-1.11)$ & 0.652 \\
\hline $\mathrm{TG} \geq 1.7 \mathrm{mmol} / \mathrm{l}$ & $2.90(2.62-3.21)$ & $<0.001$ & $1.77(1.57-2.00)$ & $<0.001$ \\
\hline Waist $\geq 102$ for males, $\geq 88$ for females & $3.74(3.40-4.12)$ & $<0.001$ & $2.33(2.09-2.60)$ & $<0.001$ \\
\hline Glucose $\geq 5.6 \mathrm{mmol} / \mathrm{l}$ & $3.24(2.91-3.62)$ & $<0.001$ & $1.85(1.63-2.10)$ & $<0.001$ \\
\hline $\mathrm{Lp}(\mathrm{a}) \geq 9 \mathrm{mg} / \mathrm{dl}$ & $1.24(1.14-1.35)$ & $<0.001$ & $1.10(1.00-1.22)$ & 0.053 \\
\hline
\end{tabular}

*The value " 0 " corresponded to a factor level less than the threshold value, and the value "1" was assigned otherwise. * $P$-values for the Wald test for regression coefficients in univariate and multivariate logistic regression models. Abbreviations: see Table I.

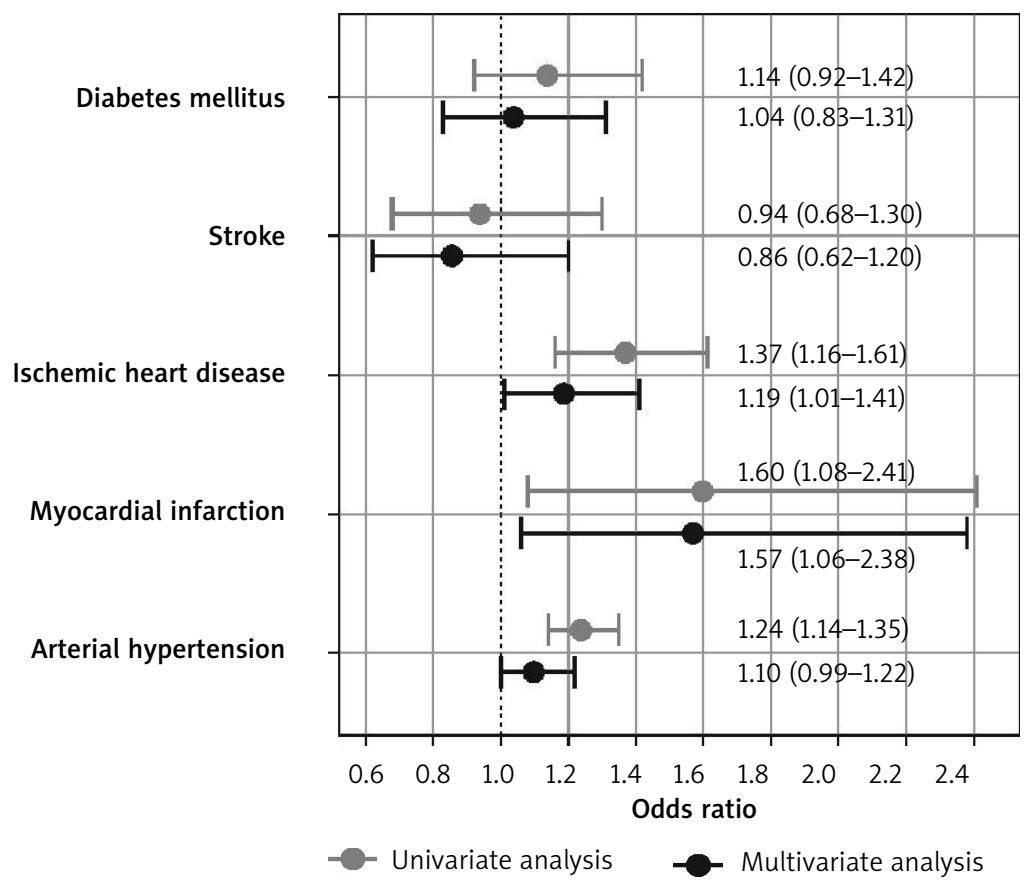

Figure 2. Associations of high lipoprotein(a) level $(\geq 9 \mathrm{mg} / \mathrm{dl})$ with diseases. Univariate and multivariate analysis

$p=0.028)$ remained significant. After adjustment, $\mathrm{Lp}(\mathrm{a})$ remained significantly associated with IHD and MI, while the association of LDL-Ccorr was lost.

\section{Discussion}

This new analysis of the ESSE-RF epidemiology project revealed several important data concerning the large sample of adults from the Russian population. First, the prevalence of HLp(a) based on a $30 \mathrm{mg} / \mathrm{dl}$ threshold is $21 \%$, whereas on a $50 \mathrm{mg} / \mathrm{dl}$ threshold it is about $13 \%$. Second, the cut-off value for Lp(a) level, above which the risk of IHD and MI starts to increase, is $9 \mathrm{mg} / \mathrm{dl}$. Third, Lp(a) level is associated with the presence of IHD and MI, but not stroke or DM or $\mathrm{AH}$.

If we take the $50 \mathrm{mg} / \mathrm{dl}$ cut-off point proposed in the European guidelines for the management of dyslipidemia, the prevalence of HLp(a) in Russia is significantly lower than that in Denmark: 13 vs. $20 \%$, respectively [1]. As in Denmark, the prevalence of elevated $L p(a)$ in Russia is comparable in men and women. However, the average level of $\operatorname{Lp}(\mathrm{a})$ and the prevalence of HLp(a) were higher in women after menopause than among younger women, as reported earlier [15]. 
The link between Lp(a) and IHD and its complications, including $\mathrm{MI}$, has been established in many studies $[2,3,9]$ and subsequently summarized $[5,7]$. It should be emphasized that this relationship does not depend on classical risk factors, including elevated cholesterol level, and does not have clear threshold values. Moreover, Lp(a) level is relatively constant and is not affected significantly by statins [16] or ezetimibe [17] and is moderately decreased by proprotein convertase subtilisin/kexin type 9 inhibitors [18].

As shown previously and in our study, it is especially important to take into account the fact that the $L p(a)$ particle consists of LDL-C at a level of $30-45 \%$. Therefore, in both clinical studies and real clinical settings it is necessary to calculate the LDL-C level corrected for Lp(a)-cholesterol content [19]. A Framingham study showed a positive correlation between LDL-C and Lp(a)-cholesterol in men $(r=0.146, p \leq 0.0011)$, which disappeared when LDL-C was corrected for $\mathrm{Lp}(\mathrm{a})$-cholesterol $(r=-0.028, p=0.3)$ [20]. The fact that the association of $\operatorname{Lp}(\mathrm{a})$ with IHD in our study starts at the $9 \mathrm{mg} / \mathrm{dl}$ level agrees with the data from the Copenhagen study [9]. In the Framingham Heart Study, the $75^{\text {th }}$ percentile $\mathrm{Lp}(\mathrm{a})$-cholesterol (> $10 \mathrm{mg} / \mathrm{dl}$ ) was chosen as the threshold and corresponds to an Lp(a) mass > $34.4 \mathrm{mg} / \mathrm{dl}$.

In our study, no relationship between $L p(a)$ level and stroke was established. Previously different studies have demonstrated an association of $L p(a)$ with stroke [21-23] or no association [24, 25]. Considering that we recently found a positive association between $\mathrm{Lp}(\mathrm{a})$ level and stenotic atherosclerosis of the carotid arteries [26], further studies in the Russian population, including subjects with cerebrovascular disease, are needed.

Univariate analysis revealed an association of $\mathrm{Lp}(\mathrm{a})$ with $\mathrm{AH}$, which disappeared in multivariate analysis. This indicates, first, the absence of a direct relationship between these factors. Second, the presence of this correlation may be indirect and reflect a role of $\mathrm{LP}(\mathrm{a})$ in damaging target organs in both $\mathrm{AH}$ and atherosclerosis [27, 28].

Finally, we did not establish a relationship between $L p(a)$ and DM. In contrast to the clear positive relationship between $L p(a)$ and ASCVD, a paradoxical inverse relationship between elevated $\mathrm{Lp}(\mathrm{a})$ and the risk of DM was previously observed $[24,25]$. This phenomenon remains unexplained.

This is a cross-sectional study with self-reported disease outcomes in the past. Whilst this might be a serious limitation in a study of such design, it may not be so in our case because the $L p(a)$ level is genetically determined and fairly constant through life, and its observed association with ASCVD may be related to its lifelong effect on vessels. Taking into account recent data on the asso- ciation of Lp(a) level with cardiovascular mortality in primary cardiovascular prevention [31], prospective observation is currently being performed within the framework of the ESSE-RF. This will provide invaluable information about $L p(a)$ as a prognostic factor in the Russian population.

In conclusion, an Lp(a) level more than $30 \mathrm{mg} / \mathrm{dl}$ is detected in every fifth adult aged 25-64 years. A significant association of Lp(a) level above $9 \mathrm{mg} / \mathrm{dl}$ with the presence of IHD and MI has been found.

\section{Conflict of interest}

The authors declare no conflict of interest.

\section{References}

1. Nordestgaard BG, Chapman MJ, Ray K, et al. Lipoprotein(a) as a cardiovascular risk factor: current status. Eur Heart I 2010; 31: 2844-53.

2. Erqou S, Kaptoge S, Perry PL, et al. Lipoprotein(a) concentration and the risk of coronary heart disease, stroke, and nonvascular mortality. JAMA 2009; 302: 412-23.

3. Clarke R, Peden JF, Hopewell JC, et al., PROCARDIS Consortium. Genetic variants associated with Lp(a) lipoprotein level and coronary disease. N Engl J Med 2009; 361: 2518-28.

4. Katsiki N, Al-Rasadi K, Mikhailidis DP. Lipoprotein (a) and cardiovascular risk: the show must go on. Curr Med Chem 2017; 24: 989-1006.

5. Cybulska B, Kłosiewicz-Latoszek L, Penson PE, Banach M. What do we know about the role of lipoprotein(a) in atherogenesis 57 years after its discovery? Prog Cardiovasc Dis 2020; 63: 219-27.

6. Mach F, Baigent C, Catapano AL, et al. 2019 ESC/EAS Guidelines for the management of dyslipidaemias: lipid modification to reduce cardiovascular risk. Eur Heart J 2020; 41: 111-88

7. Tsimikas S, Fazio S, Ferdinand KC, et al. NHLBI Working Group Recommendations to reduce lipoprotein(a)-mediated risk of cardiovascular disease and aortic stenosis. J Am Coll Cardiol 2018; 71: 177-92.

8. Anderson TJ, Grégoire J, Pearson GJ, et al. 2016 Canadian Cardiovascular Society Guidelines for the management of dyslipidemia for the prevention of cardiovascular disease in the adult. Can J Cardiol 2016; 32: 1263-82.

9. Kamstrup PR, Benn M, Tybjaerg-Hansen A, Nordestgaard BG. Extreme lipoprotein(a) levels and risk of myocardial infarction in the general population: the Copenhagen City Heart Study. Circulation 2008; 117: 176-84.

10. Ezhov MV, Safarova MS, Afanasieva OI, Kukharchuk VV, Pokrovsky SN. Lipoprotein(a) level and apolipoprotein(a) phenotype as predictors of long-term cardiovascular outcomes after coronary artery bypass grafting. Atherosclerosis 2014; 235: 477-82.

11. Pokrovsky SN, Afanasieva Ol, Ezhov MV. Lipoprotein(a) apheresis. Curr Opin Lipidol 2016; 27: 351-8.

12. Kontsevaya A, Shalnova S, Deev A, et al. Overweight and obesity in the Russian Population: prevalence in adults and association with socioeconomic parameters and cardiovascular risk factors. Obes Facts 2019; 12: 103-14.

13. Dahlen GM. Incidence of $L p(a)$ lipoprotein among populations. In: Scanu AM (ed.). Lipoprotein(a): 25 Years in Progress. Academic Press Inc.; 1990: 151-73. 
14. Xavier R, Turck N, Hainard A, et al. pROC: an open-source package for $\mathrm{R}$ and $\mathrm{S}+$ to analyze and compare $\mathrm{ROC}$ curves. BMC Bioinformatics 2011; 12: 77.

15. Jenner JL, Ordovas JM, Lamon-Fava S, et al. Effects of age, sex and menopausal status on plasma lipoprotein(a) levels. The Framingham Offspring Study. Circulation 1993; 87: 1135-41.

16. Banach M, Penson PE. Statins and Lp(a): do not make perfect the enemy of excellent. Eur Heart J 2020; 41: 190-1.

17. Awad K, Mikhailidis DP, Katsiki N, Muntner P, Banach M; Lipid and Blood Pressure Meta-Analysis Collaboration (LBPMC) Group. Effect of ezetimibe monotherapy on plasma lipoprotein(a) concentrations in patients with primary hypercholesterolemia: a systematic review and meta-analysis of randomized controlled trials. Drugs 2018; 78: 453-62.

18. Toth PP, Jones SR, Monsalvo ML, Elliott-Davey M, López JAG, Banach $M$. Effect of evolocumab on nonhigh-density lipoprotein cholesterol, apolipoprotein B, and lipoprotein(a): a pooled analysis of phase 2 and phase 3 studies. J Am Heart Assoc 2020; 9: e014129.

19. Yeang C, Witztum JL, Tsimikas S. 'LDL-C'=LDL-C+Lp(a)-C. implications of achieved ultra-low LDL-C levels in the proprotein convertase subtilisin/kexin type 9 era of potent LDL-C lowering. Curr Opin Lipidol 2015; 26: 169-78.

20. Seman LJ, DeLuca C, Jenner JL, et al. Lipoprotein(a)-cholesterol and coronary heart disease in the Framingham Heart Study. Clin Chem 1999; 45: 1039-46.

21. Aronis KN, Zhao D, Hoogeveen RC, et al. Associations of lipoprotein(a) levels with incident atrial fibrillation and ischemic stroke: the ARIC (Atherosclerosis Risk in Communities) Study. J Am Heart Assoc 2017; 6: e007372.

22. Zhang J, Du R, Peng K, et al. Serum lipoprotein (a) is associated with increased risk of stroke in Chinese adults: a prospective study. Atherosclerosis 2019; 289: 8-13.

23. Fu H, Zhang D, Zhu R, et al. Association between lipoprotein(a) concentration and the risk of stroke in the Chinese Han population: a retrospective case-control study. Ann Transl Med 2020; 8: 212.

24. Pan Y, Li H, Wang Y, Meng X, Wang Y. Causal effect of $\operatorname{Lp}(\mathrm{a})$ [lipoprotein(a)] level on ischemic stroke and Alzheimer disease: a Mendelian randomization study. Stroke 2019; 50: 3532-9.

25. Brandt EJ, Mani A, Spatz ES, Desai NR, Nasir K. Lipoprotein(a) levels and association with myocardial infarction and stroke in a nationally representative cross-sectional US cohort. J Clin Lipidol 2020; 14: 695-706.e4.

26. Tmoyan N, Ezhov M, Afanasieva O, et al. The role of lipoprotein(a) and apolipoprotein(a) phenotypes in severe atherosclerosis of coronary, carotid and lower limbs arteries. Atherosclerosis 2018; 275: e162.

27. Tangvarasittichai S, Pingmuanglaew P, Tangvarasittichai O. Association of elevated serum lipoprotein(a), inflammation, oxidative stress and chronic kidney disease with hypertension in non-diabetes hypertensive patients. Indian J Clin Biochem 2016; 31: 446-51.

28. Wang Y, Ma H, Yang J, Chen Q, Lu L, Zhang R. Lipoprotein(a) is associated with left ventricular systolic dysfunction in a Chinese population of patients with hypertension and without coronary artery disease. Arch Med Sci 2017; 13: 1078-85.

29. Kamstrup PR, Nordestgaard BG. Lipoprotein(a) concentrations, isoform size, and risk of type 2 diabetes: a Mendelian randomisation study. Lancet Diabetes Endocrinol 2013; 1: 220-7.
30. Gudbjartsson DF, Thorgeirsson G, Sulem P, et al. Lipoprotein(a) concentration and risks of cardiovascular disease and diabetes. J Am Coll Cardiol 2019; 74: 2982-94.

31. Fogacci F, D'Addato S, Cicero AFG, et al. Serum lipoprotein(a) level as long-term predictor of cardiovascular mortality in a large sample of subjects in primary cardiovascular prevention: data from the Brisighella Heart Study. Eur J Intern Med 2017; 37: 49-55. 